\title{
How the Tax Amnesty Affects the State Revenue Tax Sector in Indonesia
}

\author{
Mahda Henna ${ }^{1}$, Deki Fermansyah ${ }^{2}$, Sulistiyono3 \\ \{mahdahenna08@gmail.com ${ }^{1}$, dekifermansyah@ radenintan.ac.id ${ }^{2}$, \\ Sulistiyonouinlampung@gmail.com ${ }^{3}$ \} \\ ${ }^{1,2,3}$ State Islamic University Raden Intan Lampung, J1. Letnal Kolonel Endro Suratmin, \\ Sukarame, Bandar Lampung, Indonesia
}

\begin{abstract}
Tax amnesty be elected by governments in several countries to increase tax revenue. This study was made on the effect of the tax amnesty on the tax revenue of the state tax sector. This research was quantitative research. To collect the data and information obtained, the researcher used secondary data from dashboard tax amnesty and APBN report per July 1, 2016 - March 31, 2017. This research used tax amnesty and state revenue of tax sector. Data analysis was done by using simple linear regression analysis with eviews for Window Version 8. The result of this research indicated that tax amnesty had no significant effect to increase tax revenue of state in Indonesia.
\end{abstract}

Keywords : Tax amnesty and state revenue tax sector

\section{Introduction}

The continuity of national development has been aimed at improving people's welfare both material and spiritual. To realize it, we need to consider a considerable development budget which one of them is tax revenue. In which tax revenue is currently still the largest contributor to the country's income with an average contribution of $77.6 \%$ [1]. Target of tax receipts in 2015 is $\mathrm{Rp} \mathrm{1,294}$ Trillion increased from the year 2014 which is only $\mathrm{Rp} 1075$ Trillion[2]. While in 2016 the realization of tax revenues again increased by Rp 1.355 trillion. In Indonesia the tax potential is very great, because inhabitants in Indonesia more than 250 million, and figure 124 million in a productive period of time category in Indonesia [3].

The dominance of taxes as a source of revenue is a very natural thing, especially when natural resources, especially petroleum can no longer be relied upon. Revenue from natural resources has a relatively limited age, one day will be exhausted and can not be renewed. The situation is different from tax, in this sources of income has infinite age, especially with the increasing number of population[4]. Since taxes are said to be the main source of state revenues, it is natural that taxes can sustain most of the needs of the Indonesian people whose goal is to bring prosperity to all Indonesian citizens. However, in reality, the tax revenue collected so far has not been able to reduce the poverty rate in Indonesia [5]. In this case, the tax is still not able to overcome various problems that exist, such as malnutrition, famine, destruction of public facilities and infrastructure, still uneven in Indonesia development and various other problems. 
The fact that happened in Indonesia increasingly exacerbated by the tax revenue of Indonesia in 2015 which is said to be quite critical. Based on data compiled from the official website of the Directorate General of Taxation said that the tax target originally estimated to reach Rp1.294 trillion by 2015 was only realized as much as Rp. 1,055 trillion. This proves that the tax absorption is only $82 \%$. The failure of the Directorate General of Taxation (DJP) in realizing tax revenue makes the government must work hard to increase tax revenue one of them is by holding a tax forgiveness policy or better known as Tax Amnesty[6]. Tax amnesty is not a new policy whereby the tax amnesty policy has been implemented in several countries, such as India, Ireland, Colombia and the US state of Kolorado. Indian tax pardons conducted in 1997 were able to increase tax revenues threefold from the amount earned in previous tax amnesty. In addition, tax pardons in Ireland in 1988 obtained tax receipts that reached fifteen times the targeted tax revenue of $\$ 50$ million. Tax amnesty in Colombia in 1987 was able to raise state revenues to 100 million dollars and contribute $0.3 \%$ of Gross Domestic Product. While in Kolorado, tax forgiveness can increase state revenues by $\$ 63$ million over the estimated target of \$ 50 million[7].

The contact between tax amnesties and state revenue has been empirically be examined (Alm and Beck 1990, Dubin, Graetz, and Wilde 1992, Alm and Beck 1993, Luitel and Sobel 2007). On the other hand Luitel and Mahar (2013) found that the government did not earn significant revenue with the tax amnesty program[8]. A US state study covering 76 amnesties in 23 years concludes that short-term income is accrued as a result of the country's first amnesty, accompanied by long-term revenue losses [9]. Amnesty taxes only contribute a little in increasing revenues but can have a significant impact on taxpayer compliance decline therefore the government should prevent honest taxpayers being exploited in the process [10]. Empirical research shows that tax amnesty is not an effective solution to bring nonfilers back into the system. Additional long-term income derived from new payers is very small and can be easily offset by the effect of compliance reduction[11]. Based on the above background, the researcher wants to see whether the tax amnesty in Indonesia can increase the tax revenue.

\section{Literature Review}

\subsection{Concept of Tax Amnesty}

Tax is a dominnat source of state revenue in many countries. The amnesty tax includes forgiveness of tax obligations up to the end of the Fiscal Year, which has not yet been fully resolved by the Taxpayer, which includes: income tax and value added tax / value added tax and sales tax on luxury goods. In Indonesian government, tax amnesty was conducted, such as some taxpayers avoided paying their liabilities by taking the happening actions :(1) To help their wealth elsewhere and deposit it in dissimilar kinds of investments such as properties and stocks without recording those assets in their annual tax file; (b) To save their wealth in the form of deposits or stocks without recording those assets in their annual tax file; (c) To keep their wealth in Indonesia in the form of belongings without recording those assets in their annual tax file; (d) authority to their wealth to others who do not have a taxpayer identification number; (e) To supply their wealth in illegal businesses [12].

The meaning of the tax amnesty program is to: (1) To advance the growth and the restructuring of the economy using the reestabilishment of assets, (2) To help the tax reform in creating a system of taxation based on justice and for the expansion of basis of data of tax, (3) To increase tax revenues [2]. In his study stated that the main benefit of the holding of tax amnesty is to increase short-term state revenue Research conducted by Maulina Ulfanur (2017) shows that the impact of tax amnesty on tax revenues closely related to the Indonesian 
economy is that state revenues increase through the expansion of the tax base, increasing the state budget, increasing state revenues, spurring economic growth, and improving the value of assets owned compulsory tax [13].

On the other hand, research conducted by Emmiryzan (2017) indicates that the tax amnesty law in Indonesia is not effective because the targeted results through the government are not achieved [15]. The government does not earn significant revenue with the tax amnesty program. This shows that tax amnesty is difficult to have long-term effects, especially on state revenues [14].

\subsection{State Revenue}

State revenue can be interpreted as state revenue in the broadest sense that includes tax revenue, non-tax state revenue (PNBP) and grants. Until now, the structure of state income is still dominated by tax revenues, especially domestic tax revenues from the non-oil sector. Where taxes are levies imposed by the government (central / regional) on certain taxpayers by law (the imposition can be imposed) without any compensation directly for the payer.Tax collection must be in accordance with the two functions of the tax budgeter function and regular function[15]. The most of the practical work on tax amnesties has been done in the context of developed countries, and follows from the theoretical model of behavior under an amnesty derived by Alm and Beck [16]. While the regulerend function, the tax is not solely to include as much money in the state treasury, but also can be used as a tool to achieve the state's goal. The problem of tax revenue that tends to stagnate or decline is often the reason given tax amnesty[17]. The government hopes that with tax amnesty there will be a significant increase in tax payments during the tax amnesty. James Andreoni (1991) says that tax amnesty can influential in increasing tax payments and tax compliance [18].

\section{Hypothesis Development}

Tax amnesty is a time-limited opportunity to certain groups of taxpayers to bills a certain amount of taxes as a pardon for the obligation to pay taxes (including the abolition of interest and penalties) relating to the previous tax period without fear of criminal prosecution. The effects of the amnesties on tax collections therefore emerged as a matter of concern for the tax authorities [19]. Tax amnesties are needed to attract community groups that have not yet entered into the tax administration to enter and come part of the tax administration so as to participate in state development[20]. Alm (2009) said that tax amnesty has a positive impact on tax revenue[19]. Be based in this, the hypothesis proposed in this study is as follow:

\section{H1: Tax amnesty has a significant effect toward tax revenue.}

\subsection{Theoretical Framework}

The theoretical framework which examines the effect tax amnesty toward the state tax revenue can be seen in the following figure: 


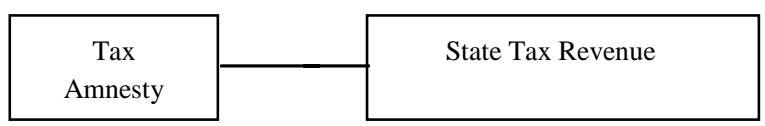

Figure 1: Theoretical Framework of the Study

\section{Research Methods}

This research was a quantitative research. To collect the data and information obtained in this purpose, the researcher used secondary data from the dashboard tax amnesty report and APBN report per July 1, 2016 - March 31, 2017. Data processor used was the eviews program version 8 .

\subsection{Linear Regression}

Linear regression was used to find out how big the influence of independent variables to the dependent variable using econometric model by regressing the existing variables by using the method of OLS (Ordinary Least Square). Independent variables affecting the dependent variable expressed in the function as follow:

$$
\mathrm{Y}_{1}=\mathrm{a}+\mathrm{b}_{1} \mathrm{X}_{1}+\mathrm{e}
$$

\subsection{Hypothesis Testing}

Regression analysis in this research was used to test hypothesis. Hypothesis in this research was tax amnesty program have a significant result to tax sector revenue. For this purpose in this research, using $\mathrm{p}$-value and $\beta$-value was considered. In this research, for a significant relationship $\mathrm{p}$-value should be less than $0.05(\mathrm{p} \leq 0.05)$.

\section{Analysis}

\subsection{Descriptive Analysis}

Table Full Model Regression

Variable Coefficient Std. Error t-Statistic Prob.

\begin{tabular}{lllll}
\hline \hline $\mathrm{C}$ & $9.22 \mathrm{E}+13$ & $2.54 \mathrm{E}+13$ & 3.626046 & 0.0084 \\
$\mathrm{X}$ & 1.263086 & 0.818012 & 1.544093 & 0.1665 \\
\hline \hline
\end{tabular}

a. Dependent Variable: Y

With Equation of regression:

$$
\mathrm{Y}=\mathrm{a}+\beta 1 \mathrm{X}+\mathrm{e}
$$




$$
\begin{array}{ll} 
& \text { In which: } \\
\mathrm{Y} & =\text { State Revenue } \\
\mathrm{X} & =\text { Tax amnesty } \\
\mathrm{e} & =\text { Error }
\end{array}
$$

Results obtained from Full Model Regression

$$
\mathrm{PN}=\mathbf{9 . 2 1 9 8 2 5 9 0 6 4 2 + 1 . 2 6 3 0 8 6 \mathrm { X }}
$$

The total realization of tax amnesty for three periods is $135,346,920,000,000$, while tax revenue from 1 July 2016 to 31 March 2017 reaches 1.020.000.000.000.000. This means that the tax amnesty only accounts for about $13.5 \%$ of total tax revenues for the period July 1 , 2016 - March 31, 2017 and only 0.91\% of total Gross Domestic Product (GDP). This is in line with the results of research conducted by researchers with using a simple linear regression model where the results of research using statistical $t$ test states that the value of significance of $0.166>0.05$ and the value of tcount 1.544 <ttabel of 2.3646. Then it shows that the hypothesis is rejected which means tax amnesty has no significant effect on the state revenue in Indonesia.

The realization of tax amnesty acceptance in accordance with SSP (Tax Payment Deposit) did reach $\mathrm{Rp} 134.99$ trillion, with ransom of $\mathrm{Rp} 114.23$ trillion, payment of arrears of $\mathrm{Rp}$ 19.02 trillion and preliminary evidence inclusion of $\mathrm{Rp} 1.75$ trillion[6]. This indicates that the country did receive tax revenue of $135 \mathrm{~T}$ but tax revenue in 2016 actually decreased. Because, if it does not include tax amnesty, 2016 tax revenues will only amount to Rp 992 trillion, or about 73.2 percent of the 2016 Budget Revised target of $\mathrm{Rp} 1,355$ trillion. While in the previous year, in 2015, total tax revenues amounted to $\mathrm{Rp} 1,060$ trillion, or about 81.9 percent of the 2015 Revised State Budget target of Rp 1,294 trillion. So in this case it appears that tax revenue has decreased. This shows that tax amnesty is difficult to have long-term effects, especially on state revenues. The results of this study are in line with research by Buckwalter (2014) The tax amnesty programs is not suggest for the government to conduct a repeated series, as it would destroy the government's credibility[21].

\section{Conclusions}

The result of the research concludes that amnesty does not significantly affect the state revenue. The tax amnesty program in Indonesia took happen a period of several months, since 1 July 2016 until 31 March 2017. The several month implementation period was share into three phases, of which (1) since 1 July 2016 until 30 September 2016, (2) since 1 October 2016 until 31 December 2016, and (3) since 1 January 2017 until 31 March 2017 [13]. The empirical data shows that tax amnesty proved less effective in increasing tax revenue in Indonesia. Because the tax amnesty is only able to contribute about $13.5 \%$ of total tax revenue for the period July 1, 2016 - March 31, 2017 and only 0.91\% of total Gross Domestic Product (GDP). It shows that the government does not earn significant revenue with the program tax amnesty.Because the government is only able to encompass lower taxpayers while taxpayers agencies and among large entrepreneurs are still many of them who do not participate forgiveness, which resulted in even though many taxpayers who participated tax amnesty but the received revenue is not too significant. 
Further improvement of the business climate and investment climate in Indonesia should also be improved so that the funds that are parked abroad can return to Indonesia and can be invested into the real sector that exists in the country that could have an impact on development in Indonesia. When the business climate and investment in the country can compete with in other countries then the entrepreneurs will think to invest it in Indonesia. Thus, it is important to promote the tax authorities in requesting report about tax payer wealth data to banks in the country.

Stronger law enforcement and taxpayer trust to tax officials (tax authorities) to be one point to increase state revenues. The reason is still a lot of taxpayers who think that in practice there is still a lot of tax evasion made by upper class taxpayers, this causes a decrease in compliance level other taxpayers because affected by the behavior of others. When a person does not obey his obligations to the state, then there is the potential of others who will follow the same issues. Therefore, a more just and assertive law enforcement, improving the business climate or domestic investment, in addition to reforming the tax system become an important point in increasing state revenues.

\section{References}

[1] M. Wenzel, "An analysis of norm processes in tax compliance," J. Econ. Psychol., 2004.

[2] Undang-Undang No 11, “Undang-Undang-Republik-Indonesia-Nomor-11-Tahun2016-Tentang-Pengampunan-Pajak," IOSR J. Econ. Financ., 2016.

[3] Badan Pusat Statistika, "No Title," https://www.bps.go.id/linkTabelStatis/view/id/971, 2017. [Online]. Available: https://www.bps.go.id/linkTabelStatis/view/id/971.

[4] M. Wenzel, "Misperceptions of social norms about tax compliance: From theory to intervention," J. Econ. Psychol., 2005.

[5] T. Suryanto, F. Purnamasari, and M. Kurniawan, "Tax Revenue and Disparity: How to Improvement Income Inequality in Islamic Perspective," Asian J. Soc. Sci. Manag. Stud., 2018.

[6] Direktorat Jenderal Pajak, "Direktorat Jenderal Pajak," Directorate General of Taxation of the Republic of Indonesia Statistik Amnesti Pajak. [Online]. Available: http://www.pajak.go.id/statistik-amnesti.

[7] B. Torgler, "Tax Morale: Theory and Empirical Analysis of Tax Compliance," PhD Thesis, 2003.

[8] H. S. Luitel and G. J. Mahar, "Is a Tax Amnesty a Good Fiscal Policy? A Review of State Experience in the USA," SSRN Electron. J., 2013.

[9] H. S. Luitel and R. S. Sobel, "The Revenue Impact of Repeated Tax Amnesties," Public Budg. Financ., 2007.

[10] L. P. Feld and B. S. Frey, "Trust breeds trust: How taxpayers are treated," Econ. Gov., 2002.

[11] R. Fisher, J. Goddeeris, and J. Young, "Participation in Tax Amnesties: The Individual Income Tax," Natl. Tax J., 1989.

[12] E. Said, "Tax Policy in Action: 2016 Tax Amnesty Experience of the Republic of Indonesia," Laws, 2017.

[13] M. Ulfanur, "Kebijakan Tax Amnesty dalam Perspektif Ekonomi Islam (Studi Kasus di KPP Pratama Langsa)," 2017.

[14] "Tax Amnesties and Compliance in the Long Run: A Time Series Analysis," Natl. Tax 
$J ., 1993$.

[15] Kementerian Keuangan, "Kementerian Keuangan." [Online]. Available: https://www.kemenkeu.go.id/.

[16] J. Alm and W. Beck, "Wiping the Slate Clean: Individual Response to State Tax Amnesties," South. Econ. J., 1991.

[17] Syafrida and F. Nurhayati, "Analisis Penerapan Tax Amnesty di Indonesia dalam Rangka Meningkatkan Penerimaan Negara pada Sektor Perpajakan,” J. Ilm. Univ. Bakrie, 2015.

[18] J. Andreoni, "The desirability of a permanent tax amnesty," J. Public Econ., 1991.

[19] J. Alm, J. Martinez-Vazquez, and S. Wallace, "Do Tax Amnesties Work? The Revenue Effects of Tax Amnesties During the Transition in the Russian Federation," Econ. Anal. Policy, 2009.

[20] N. A. Jamil, "Efektivitas Penerapan Tax Amnesty di Indonesia," Acad. J. Multidiscip. Stud., 2017.

[21] N. D. Buckwalter, N. Y. Sharp, J. H. Wilde, and D. A. Wood, "Are State Tax Amnesty Programs Associated with Financial Reporting Irregularities?," Public Financ. Rev., 2014. 